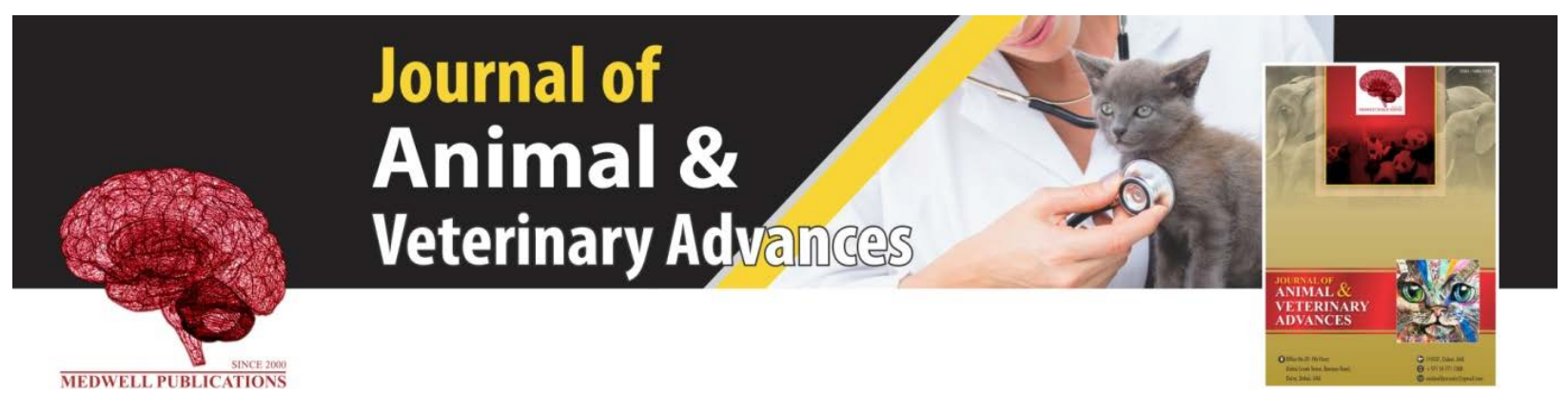

\title{
Effects of Milk Thistle, Artichoke and Olive Extracts in Comparison with Atorvastatin and Gemfibrozil on Liver Function in Broiler Chicken
}

\author{
Fatemeh Tavakolinasab, Heshmatollah Khosravinia and Babak Masouri \\ Department of Animal Sciences, Faculty of Agriculture, Lorestan University, Lorestan, Iran
}

Key words: Atorvastatin, broiler chicken, gemfibrozil, hepatoprotection, herbal medicine

\section{Corresponding Author:}

Heshmatollah Khosravinia

Department of Animal Sciences, Faculty of Agriculture, Lorestan University, P.O. Box 465, Khorramabad 68137-17133, Lorestan, Iran

Page No.: 18-25

Volume: 19, Issue 2, 2020

ISSN: 1680-5593

Journal of Animal and Veterinary Advances

Copy Right: Medwell Publications
Abstract: Two hundredeighty-eight 10-day old male Arbor Acres (320 \pm 5 g) broiler chicks were used to compare the responses in liver function to dietary supplementation of milk thistle (Silybum marianum), artichoke (Cichorium intybus) and olive (Olea europaea) extracts with gemfibrozil and atorvastatin, in broiler chickens fed with a lipogenic diet. Birds raised in the standard experimental conditions and received a pelleted grower diet (control) supplemented with milk thistle (250 mg kg ${ }^{-1}$ ), artichoke (200 $\mathrm{mg} \mathrm{kg}^{-1}$ ), olive (150 mg $\mathrm{kg}^{-1}$ ) extracts, atorvastatin (20 $\mathrm{mg} \mathrm{kg}^{-1}$ ) and gemfibrozil (1800 $\mathrm{mg} \mathrm{kg}^{-1}$ ) up to day 42 of age. Liver weight and liver fat parentage were 1.62 and $6.04 \%$, respectively, in the birds fed with the un-supplemented basal diet (control) and modified by +0.21 and $-2.13,+0.11$ and $-1.21,+0.14$ and $-1.40,-0.07$ and $-2.36,+0.07$ and $-0.38 \%$ in the birds received milk thistle, artichoke, olive extracts, gemfibrozil and atorvastatin, respectively. The milk thistle-added diet elicited significant reduction in serum activity of Aspartate amino transferase and Alanine aminotransferase at day 35 of age. Dietary olive extract at $150 \mathrm{mg} \mathrm{kg}^{-1}$ reduced liver fat at day 35 of age compared with those grown on the basal diet $(\mathrm{p}<0.05)$. Plasma triglycerides level was lower $(\mathrm{p}<0.05)$ in the birds fed with diets enriched with artichoke (34.86 $\mathrm{mg} \mathrm{dL}^{-1}$ ) and olive extract (40.63 $\mathrm{mg} \mathrm{dL}^{-1}$ ) compared with those fed with the supplemented control diet at day 35 of age. It was concluded that milk thistle exerted greater promising hepatoprotective effects compared with other remedies. Gemfibrozil exhibited a greater hepatoprotective and blood lipid lowering effect than atorvastatin.

\section{INTRODUCTION}

Rudimentary lymphatic system and direct absorption of chylomicrons into the portal blood ${ }^{[1]}$ predispose chickens to fat deposition in the liver ${ }^{[2]}$. It was shown that chickens develop histological hepatic changes resembling steatohepatitis when they maintained on a hyperlipidemic $\operatorname{diet}^{[1,3]}$. Sedentary life style and overfeeding due to free 
access to feed in commercial broiler flocks are two main common characteristics of chicken life. Xiao ${ }^{[4]}$, showed feeding a low-proteinand high-energy diet induced Fatty Liver Syndrome (FLS) in chicken. The same results also confirmed by Onel et al. ${ }^{[5]}$ who reported fatty liver developed in birds not able to move enough to burn the calories received.

Because of the nutritional status of the bird influences lipid metabolism in liver ${ }^{[6]}$, scientific attempts are mainly directed at identifying potential dietary therapies for FLS. During the last decade, natural products, in particular medicinal plants have gained increasing consideration to treat various metabolic disorders such as liver diseases, principally because of their multiplex properties and minimal adverse effects on the body. Addition of herbal remedies having lipotropicproperties to poultry feed may decrease undesirable metabolic concerns of the currently used high calorie diets because these additives improvefat deposition in bird's liver ${ }^{[7]}$. Antioxidant compounds as a positive aspect of phytogenic extracts by reducing lipid oxidation, peroxidation and perhaps moderating inflammation processes, denote another attractive therapeutic approach for animal models suffering from hepatic steatosis ${ }^{[8]}$. Despite of the several reports on effects of plant derived products on lipid metabolism and hepatic function, there are fewreports on comparison of their effects with the common synthetic pharmaceuticals prescribed for the same purpose in human clinical cases. Therefore, this study aimed to evaluate the responses in liver function to dietary supplementation of milk thistle (Silybum marianum), artichoke (Cynara scolymus L.) and olive (Olea europaea) extracts in comparison with the well-known synthetic therapeutic medications, gemfibrozil and atorvastatin, in broiler chickens fed with a high energy and low protein lipogenic diet.

\section{MATERIALS AND METHODS}

Birds and diets: A total of 288 healthy and uniform male Arbor Acres broiler chicks with an average weight of $320 \pm 5$ g was randomly distributed to 96 wire cages of three birds each where they acclimatized for 3 days. At the commencement of the day 14, birds weighed individually and subjected to one of the six experimental treatments concerned up to day 42 of age. Experimental treatments consisted of; a basal grower diet (Table 1; formulated based on the strain company with slight modifications in toward a lipogenic diet) inpelleted form; the basal diet supplemented with milk thistle extract (250 $\mathrm{mg} \mathrm{kg}^{-1}$ ); the same basal diet supplemented with either artichoke extract (200 $\mathrm{mg} \mathrm{kg}^{-1}$ ), olive extract (150 mg kg-1), atorvastatin (20 mg kg${ }^{-1}$ ) or gemfibrozil $\left(1800 \mathrm{mg} \mathrm{kg}^{-1}\right)$. House temperature was initially set at
Table 1: Ingredients and nutrient composition of basal diets

\begin{tabular}{|c|c|}
\hline Ingredients (\%) & Grower diet (11-42 day) \\
\hline Yellow maize & 63.08 \\
\hline Soybean meal & 31.54 \\
\hline Soybean oil & 1.50 \\
\hline Calcium phosphate & 1.40 \\
\hline $\mathrm{CaCO}_{3}$ & 1.34 \\
\hline DL-Methionine & 0.28 \\
\hline L-Lysine HCL & 0.04 \\
\hline Salt & 0.14 \\
\hline Mineral Premix ${ }^{1}$ & 0.25 \\
\hline Vitamin Premix ${ }^{2}$ & 0.25 \\
\hline Salinomycin & 0.10 \\
\hline \multicolumn{2}{|l|}{ Nutrient composition } \\
\hline $\mathrm{ME}\left(\mathrm{Kcal} \mathrm{kg}^{-1}\right)$ & 3176 \\
\hline Crude protein (\%) & 17.00 \\
\hline Lysine (\%) & 1.00 \\
\hline Potassium (\%) & 0.76 \\
\hline Methionine & 0.50 \\
\hline Methionine+Cystine (\%) & 0.55 \\
\hline L-Threonine (\%) & 0.72 \\
\hline Calcium (\%) & 0.80 \\
\hline Available P (\%) & 0.41 \\
\hline $\mathrm{Na}(\%)$ & 0.20 \\
\hline Cholorin & 0.20 \\
\hline
\end{tabular}

1 and ${ }^{2}$ Each kilogram contains Vitamin A, 12000 international units; vitamin D3; 5000 international units; vitamin E 80 units; vitamin K3; $3.2 \mathrm{mg}$; vitamin B1; $3.2 \mathrm{mg}$; vitamin B2; $8.6 \mathrm{mg}$; vitamin B3; $20 \mathrm{mg}$; vitamin B5; 65 mg; vitamin B6; 4.3 mg; vitamin B9; $2.2 \mathrm{mg}$; vitamin B12; 0.017 mg; vitamin H2; 0.30 mg; choline chloride; 1700, mg; 1000 mg antioxidant; 120,000 mg manganese; Zinc; 110000 mg; copper; 16,000 mg; selenium; $300 \mathrm{mg}$; iodine; $1250 \mathrm{mg}$; iron; 20,000 mg

$28^{\circ} \mathrm{C}$ for the second week and then reduced by $0.5^{\circ} \mathrm{C}$ per day until a temperature of $22^{\circ} \mathrm{C}$ was achieved at the end of the fourth week and then maintained constant thereafter. A 23:1 h light to darkness lightening regimen was followed throughout the experimentation period. Feed and water were supplied to the birds in each cage using a trough feeder and waterer located in the opposite sides of the cages, for ad libitum consumption throughout the experimentation period. During the experiment, no medication or antibiotic were given to the birds. Vaccination was performed against influenza, infectious bursal and bronchitis viruses in day 21 of age.

Extracts preparation: Milk thistle extract provided from Zardband Pharmaceuticals Co, Tehran-Iran. The product was commercially available extract which contained silybins A (11.52) and B (13.92), the isosilybins A (16.43) and B (17.81), silychristin A (6.68), isosilychristin (5.31), silydianin (8.51) and silymarin (80.18). Artichok extract was supplied by Soha Jissa Co, Mazandaran-Iran and its analysis revealed that it comprises caffeoylquinic acids (4.6421), luteolin-7-glucoside (0.1703), luteolin (0.1410), apigenin-7-glucoside (0.7361), caffeic acid (0.6332), chlorogenic acid (2.4731), eugenol (4.8512) and rosmarinic acid (trace amount). Olive extract (freezedried) provided from Dana Kasian Co, Khorammabad, 
Lorestan, Iran, andcontained $41.09 \%$ oleuropein as the major polyphenolic compound, followed by oleic acid (28.93\%) palmitic acid 10.15\%, linoleic acid 7.10\%, pctadecadienoic acid 5.12\%, stearic acid 4.65\%, palmitoleic acid $0.98 \%$ and tridecanoic acid $1.98 \%$. The capsules of gemfibrozil (300 mg) were produced by Toliddaru Pharmaceutical Co, Tehran-Iran and the atorvastatin tablets $(20 \mathrm{mg})$ provided form Arya Pharmaceutical Co, Tehran-Iran.

Blood collection and analyses: Individual samples of coagulated whole blood were collected form the slaughtered birds and centrifuged at $1800 \times \mathrm{g}$ for $15 \mathrm{~min}$ and $5^{\circ} \mathrm{C}$. The average volume of 4-5 mlclear and non-hemolyzed serum sample was collected for each bird and preserved at $-20^{\circ} \mathrm{C}$ until required for biochemical analysis. An auto-analyzer system (Clima; Ral. Co, Barcelona, Spain) was employed to measure Glucose (GLU), Triglycerides (TG), Total Cholesterol (TC) and Low-Density Lipoprotein Cholesterol (LDL-C), Total Bilirubin (TBIL), Direct Bilirubin (DBIL), Albumin (ALB), Total Protein (TP), Low Density Lipoprotein Cholesterol (LDL-C) and the activity of Alanine aminotransferase (ALT), Aspartate aminotransferase (AST) and Lactate Dehydrogenase (LDH) in the sera samples. The analyzer system used enzymatic processes that have been defined by Elliott ${ }^{[9]}$ using SEPPIM Diagnostic Kits, in two replicates at $25^{\circ} \mathrm{C}$.

Liver parameters and scoring system: At the end of days 35 and 42 of age, one bird was taken randomly from each replicate and slaughtered by puncturing the jaguar veins and carotid arteries. The slaughtered chicken dissected to collect the data on abdominal fat percentage, liver weight, apparent liver score and liver fat content. Liver color was appraised based on a 4-garde scoring method by assigning a score from 0 to 3; 0 indicating normal liver color and 3 indicating putty-colored livers as described by Trott et al. ${ }^{[10]}$ with slight modifications. Liver lipid content was determined using Folch et al. ${ }^{[11]}$ method. Briefly, $1 \mathrm{~g}$ liver tissue as a wellprepared sample was homogenized with $20 \mathrm{~mL}$ chloroform methanol (2/1) (1 $\mathrm{g}$ in $20 \mathrm{~mL}$ of solvent mixture). After dispersion, the final mixture agitated for 20 min using an orbital shaker at $25^{\circ} \mathrm{C}$ and then agitation persisted for $2 \mathrm{~h}$. The homogenate then filtered through Whatman \#1 filter paper into a $100 \mathrm{~mL}$ graduated cylinder, following by adding $5 \mathrm{~mL}$ of $7.3 \%$ Potassium chloride solution. The new solution was mixed and left for phase separation. The top layer was collectedand remained to evaporate the solvent for $24 \mathrm{~h}$. Fat percentage was calculated when each sample was dried and weighed.

Statistical analysis: Response of the birds to the eight concerned experimental treatments was evaluated using a complete randomized block design. Considering air flow in the house as a random variable, 12 rows of cages were positioned perpendicular to the air flow direction to provide blocks with homogenious environment. The PROC Mixed in Statistical Analysis System, Version 9.1 (2003) was adopted to analyze the collected data. Finally, multiple treatment comparisonswere conducted using the Tukey test ${ }^{[12]}$. Frequency analysis using PROC FERQ in the same Statistical Analysis Software $\left(\mathrm{SAS}^{[13]}\right)$ was implemented to differentiate differences among liver health scores. For all tests, significance was declared at $5 \%(\mathrm{p}<0.05)$.

\section{RESULTS}

Plasma TG level was declined $(\mathrm{p}<0.05)$ in the birds fed with the artichoke- $\left(34.86 \mathrm{mg} \mathrm{dL}^{-1}\right)$ and olivesupplemented (40.63 $\mathrm{mg} \mathrm{dL}^{-1}$ ) diets compared with those fed with the control diet at 35 day of age. In contrast, feeding the gemfibrozil-containing diet increased plasma TG level by $10.37 \mathrm{mg} \mathrm{dL}^{-1}$ compared with the control diet $(\mathrm{p}<0.05)$. At the same age, serum concentration of GLU decreased by 23.99 and $26.83 \mathrm{mg} \mathrm{dL}^{-1}$ in broiler chicken grown on the artichoke and silymarin-added diets, respectively, compared with those fed with the control diet (191.23 $\left.\mathrm{mg} \mathrm{dL}^{-1}\right)(\mathrm{p}<0.05$; Table 2).

At 42 day of age, the plasma TG level was lesser in the birds fed gemfibrozil (42.79 $\mathrm{mg} \mathrm{dL}^{-1}$ ) while it was greater in silymarin-supplemented diets (44.48 $\mathrm{mg} \mathrm{dL}^{-1}$ ), than the birds grown on the other supplemented diets $(\mathrm{p}<0.05)$. At the same age, plasma TC level was greater (239.10 $\mathrm{mg} \mathrm{dL}^{-1}$ ) in the birds grown on the control diet and declined in the birds feeding atorvastatin, milk thistle and artichoke diets by 71.54, 60, $57.1 \mathrm{mg} \mathrm{dL}^{-1}$, respectively $(p<0.05)$. Liver fat percentage was $6.04 \%$ in the birds grown on control diet in day 35 of age $(\mathrm{p}<0.05)$ and dietary olive extract reduced liver fat by $1.58 \%$ at the same age $(\mathrm{p}<0.05$; Table 2$)$.

At day 42 of age, abdominal fat percentage was greater by 0.52 and $0.45 \%$ in the birds fed the control diet, than those received diets containing milk thistle and gemfibrozil, respectively ( $\mathrm{p}<0.05$; Fig. 1$)$. At the same age, the birds fed with the control diets showed a greater liver fat percentage $(\mathrm{p}<0.05)$ but inclusion of the control diet with silymarin and gemfibrozil significantly decreased liver fat by 2.13 and $2.36 \%$, respectively $(\mathrm{p}<0.05)$.

The mean serum activity of AST and ALT was greater in the broilers fed with the control diet in day 35 of age $(\mathrm{p}<0.05)$. Inclusion of silymarin in control diet significantly reduced serum activities for both enzymes at the same age $(\mathrm{p}<0.05$; Table 3$)$. In day 42 , serum AST activity was greater in the birds maintained on the control 
J. Anim. Vet. Adv., 19 (2): 18-25, 2020

Table 2: Mean serum concentration of lipids in broilers chickens

\begin{tabular}{|c|c|c|c|c|c|c|}
\hline \multirow[b]{2}{*}{ Treatments } & \multicolumn{4}{|l|}{$35 \mathrm{~d}$} & \multicolumn{2}{|l|}{$42 \mathrm{~d}$} \\
\hline & $\mathrm{TG}\left(\mathrm{mg} \mathrm{dL}^{-1}\right)$ & $\mathrm{TC}\left(\mathrm{mg} \mathrm{dL}^{-1}\right)$ & GLU $\left(\mathrm{mg} \mathrm{dL}^{-1}\right)$ & $\mathrm{LDL}\left(\mathrm{mg} \mathrm{dL}^{-1}\right)$ & $\mathrm{TG}\left(\mathrm{mg} \mathrm{dL}^{-1}\right)$ & $\mathrm{TC}\left(\mathrm{mg} \mathrm{dL}^{-1}\right)$ \\
\hline Control & $150.13^{\mathrm{ab}}$ & 197.50 & $191.23^{\mathrm{a}}$ & 45.12 & $133.22^{\mathrm{ab}}$ & $239.10^{\mathrm{a}}$ \\
\hline Silymarin $\left(250 \mathrm{mg} \mathrm{kg}^{-1}\right)$ & $141.10^{\mathrm{ab}}$ & 214.00 & $164.40^{\mathrm{b}}$ & 50.20 & $177.70^{\mathrm{a}}$ & $179.10^{\mathrm{b}}$ \\
\hline Artichoke (200 mg kg ${ }^{-1)}$ & $115.27^{\mathrm{b}}$ & 194.73 & $167.64^{\mathrm{b}}$ & 42.72 & $114.20^{\mathrm{bc}}$ & $182.00^{\mathrm{ab}}$ \\
\hline Olive (150 mg kg ${ }^{-1}$ ) & $109.50^{\mathrm{b}}$ & 205.30 & $175.10^{\mathrm{ab}}$ & 47.30 & $110.22^{\mathrm{b}}$ & $196.11^{\mathrm{ab}}$ \\
\hline Gemfibrozil (1800 $\mathrm{mg} \mathrm{kg}^{-1}$ ) & $160.50^{\mathrm{a}}$ & 231.17 & $196.83^{\mathrm{a}}$ & 40.66 & $90.43^{c}$ & $213.30^{\mathrm{ab}}$ \\
\hline Atorvastatin $\left(20 \mathrm{mg} \mathrm{kg}^{-1}\right)$ & $142.44^{\mathrm{ab}}$ & 201.56 & $183.11^{\mathrm{ab}}$ & 40.44 & $152.89^{\mathrm{abc}}$ & $167.56^{c}$ \\
\hline SEM & 16.141 & 13.368 & 44.131 & 4.573 & 17.071 & 19.017 \\
\hline p-value & 0.0390 & 0.3221 & 0.0213 & 0.3944 & 0.0014 & 0.0013 \\
\hline
\end{tabular}

abc Within a column, means with no common superscript differ significantly ( $\mathrm{p}<0.05)$; Triglycerides (TG), Cholesterol (TC), Glucose (GLU) and Low Density Lipoprotein (LDL), SEM = Standard Error of the Mean

Table 3: Mean proportional and absolute liver weight and fat percentage in broilers chickens

\begin{tabular}{|c|c|c|c|c|c|c|}
\hline \multirow[b]{2}{*}{ Treatments } & \multicolumn{4}{|l|}{$35 \mathrm{~d}$} & \multicolumn{2}{|l|}{$42 \mathrm{~d}$} \\
\hline & Liver (\%) & Liver (g) & Fat $(\%)$ & Liver (\%) & Liver (g) & Fat $(\%)$ \\
\hline Control & 1.71 & 21.81 & $6.04^{\mathrm{a}}$ & 1.62 & 25.00 & $6.40^{\mathrm{a}}$ \\
\hline Silymarin (250 mg kg ${ }^{-1}$ ) & 2.05 & 24.99 & $5.23^{\mathrm{ab}}$ & 1.83 & 27.30 & $4.27^{\mathrm{b}}$ \\
\hline Artichoke (200 $\left.\mathrm{mg} \mathrm{kg}^{-1}\right)$ & 2.00 & 23.52 & $4.92^{\mathrm{ab}}$ & 1.73 & 28.55 & $5.19^{\mathrm{ab}}$ \\
\hline Olive (150 mg kg${ }^{-1}$ ) & 1.97 & 22.96 & $4.46^{\mathrm{b}}$ & 1.76 & 28.04 & $5.00^{\mathrm{ab}}$ \\
\hline Gemfibrozil (1800 mg kg-1) & 1.84 & 24.14 & $4.94^{\mathrm{ab}}$ & 1.55 & 24.46 & $4.04^{\mathrm{b}}$ \\
\hline Atorvastatin $\left(20 \mathrm{mg} \mathrm{kg}^{-1}\right)$ & 1.68 & 22.07 & $4.79^{\mathrm{ab}}$ & 1.69 & 29.00 & $6.02^{\mathrm{ab}}$ \\
\hline SEM & 0.125 & 1.302 & 0.369 & 0.136 & 1.718 & 0.720 \\
\hline p-value & 0.3447 & 0.3461 & 0.0251 & 0.9748 & 0.7485 & 0.0005 \\
\hline
\end{tabular}

${ }^{\mathrm{abc}}$ Within a column with no common superscript letter differ significantly $(\mathrm{p}<0.05)$; SEM = Standard Error of the Mean

Table 4: Mean serum activity of enzymes in broilers chickens

\begin{tabular}{|c|c|c|c|c|c|c|}
\hline \multirow[b]{2}{*}{ Treatments } & \multicolumn{3}{|l|}{$35 d$} & \multicolumn{3}{|l|}{$42 \mathrm{~d}$} \\
\hline & ALT (IU/l) & AST (IU/l) & $\mathrm{LDH}(\mathrm{IU} / \mathrm{l})$ & $\mathrm{ALT}(\mathrm{IU} / \mathrm{l})$ & AST (IU/l) & $\mathrm{LDH}(\mathrm{IU} / \mathrm{l})$ \\
\hline Control & $300.33^{\mathrm{a}}$ & $8.000^{\mathrm{a}}$ & 4717.5 & 232.75 & $6.625^{\mathrm{a}}$ & $2788.8^{\mathrm{a}}$ \\
\hline Silymarin (250 mg kg-1) & $212.67^{\mathrm{b}}$ & $4.538^{\mathrm{b}}$ & 3799.7 & 238.45 & $5.545^{\mathrm{ab}}$ & $2760.1^{\mathrm{a}}$ \\
\hline Artichoke (200 mg kg-1) & $246.42^{\mathrm{ab}}$ & $6.750^{\mathrm{ab}}$ & 4628.0 & 247.90 & $6.100^{\mathrm{ab}}$ & $2370.5^{\mathrm{ab}}$ \\
\hline Olive $\left(150 \mathrm{mg} \mathrm{kg}^{-1}\right)$ & $277.50^{\mathrm{ab}}$ & $6.833^{\mathrm{ab}}$ & 4300.7 & 231.22 & $5.222^{\mathrm{ab}}$ & $2215.7^{\mathrm{ab}}$ \\
\hline Gemfibrozil (1800 mg kg-1) & $269.42^{\mathrm{ab}}$ & $7.333^{\mathrm{ab}}$ & 4546.1 & 247.00 & $6.000^{\mathrm{ab}}$ & $1795.8^{\mathrm{b}}$ \\
\hline Atorvastatin $\left(20 \mathrm{mg} \mathrm{kg}^{-1}\right)$ & $254.89^{\mathrm{ab}}$ & $6.000^{\mathrm{ab}}$ & 4740.8 & 232.78 & $4.889^{\mathrm{b}}$ & $2567.1^{\mathrm{ab}}$ \\
\hline SEM & 0.803 & 25.416 & 319.895 & 12.760 & 0.580 & 256.121 \\
\hline $\mathrm{p}$-value & 0.0205 & 0.0030 & 0.4357 & 0.8519 & 0.8065 & 0.0178 \\
\hline
\end{tabular}

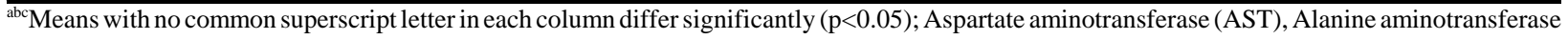
(ALT) and Lactate Dehydrogenase (LDH), SEM = Standard Error of the Mean

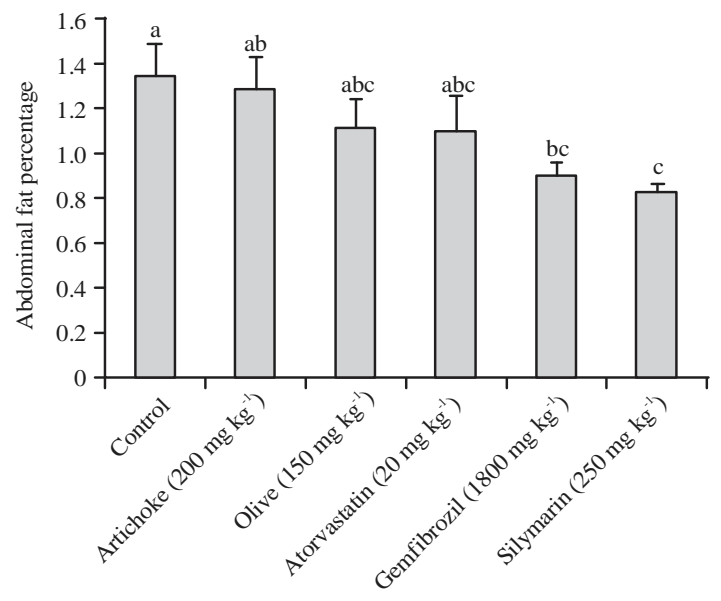

Fig. 1: Mean Abdominal Fat Percentage (AFP) in the chickens received diets supplemented with plant extracts and synthetic lipotropic additives in days 42 of age $(\mathrm{p}$-value $=0.0476$, $\mathrm{SEM}=0.128)$ diet $\left(1.736 \mathrm{U} \mathrm{L}^{-1}\right)$ than those received atorvastatin supplemented diet. Feeding the control diet also increased serum LDH activity at the same age $(\mathrm{p}<0.05)$. Inclusion of gemfibrozil into the control diet decreased LDH activity by 993 and $964 \mathrm{U} \mathrm{L} \mathrm{L}^{-1}$ compared with those fed with control and silymarin containing diets, respectively $(\mathrm{p}<0.05$; Table 4).

Serum concentration of TBIL increased in the birds fed with the gemfibrozil-containing diet compared with the other birds at day 35 of age $(p<0.05)$. Serum concentration of DBIL and ALB reduced in the birds receiving the silymarin-supplemented diet, whereas feeding the gemfibrozil-added diet significantly increased both parameters at the same age $(\mathrm{p}<0.05)$. At the end of experiment, serum ALB concentration was further increased in the birds received the control diet $(\mathrm{p}<0.05)$. Supplementation of the diet with artichoke and olive extract as well as atorvastatin significantly decreased serum ALB $(\mathrm{p}<0.05)$. Serum TP concentration increased 
J. Anim. Vet. Adv., 19 (2): 18-25, 2020

Table 5: Values of the main plasma parameters in broilers chickens

\begin{tabular}{|c|c|c|c|c|c|c|c|c|}
\hline \multirow[b]{2}{*}{ Treatments } & \multicolumn{4}{|l|}{$35 d$} & \multicolumn{4}{|l|}{$42 \mathrm{~d}$} \\
\hline & $\begin{array}{c}\text { TBIL } \\
\left(\mathrm{mg} \mathrm{dL}^{-1}\right) \\
\end{array}$ & $\begin{array}{c}\text { DBIL } \\
\left(\mathrm{mg} \mathrm{dL}^{-1}\right)\end{array}$ & $\begin{array}{c}\text { ALB } \\
\left(\mathrm{g} \mathrm{dL}^{-1}\right) \\
\end{array}$ & $\begin{array}{c}\mathrm{TP} \\
\left(\mathrm{g} \mathrm{dL}^{-1}\right) \\
\end{array}$ & $\begin{array}{c}\text { TBIL } \\
\left(\mathrm{mg} \mathrm{dL}^{-1}\right)\end{array}$ & $\begin{array}{c}\text { DBIL } \\
\left(\mathrm{mg} \mathrm{dL}^{-1}\right)\end{array}$ & $\begin{array}{c}\mathrm{ALB} \\
\left(\mathrm{g} \mathrm{dL}^{-1}\right)\end{array}$ & $\begin{array}{c}\mathrm{TP} \\
\left(\mathrm{g} / \mathrm{dL}^{-1}\right) \\
\end{array}$ \\
\hline Control & $0.375^{\mathrm{b}}$ & $0.079^{\mathrm{ab}}$ & $1.838^{\mathrm{ab}}$ & 5.61 & 0.350 & 0.057 & $2.262^{\mathrm{a}}$ & $5.11^{\mathrm{a}}$ \\
\hline Silymarin (250 mg kg ${ }^{-1}$ ) & $0.400^{\mathrm{b}}$ & $0.061^{\mathrm{b}}$ & $1.633^{\mathrm{b}}$ & 4.72 & 0.336 & 0.056 & $2.127^{\mathrm{ab}}$ & $4.42^{\mathrm{b}}$ \\
\hline Artichoke (200 mg kg-1) & $0.433^{\mathrm{b}}$ & $0.075^{\mathrm{ab}}$ & $1.800^{\mathrm{ab}}$ & 4.72 & 0.440 & 0.058 & $2.100^{\mathrm{b}}$ & $4.31^{\mathrm{b}}$ \\
\hline Olive (150 $\left.\mathrm{mg} \mathrm{kg}^{-1}\right)$ & $0.416^{\mathrm{b}}$ & $0.070^{\mathrm{ab}}$ & $1.791^{\mathrm{ab}}$ & 4.53 & 0.344 & 0.056 & $2.077^{\mathrm{b}}$ & $4.61^{\mathrm{b}}$ \\
\hline Gemfibrozil (1800 $\left.\mathrm{mg} \mathrm{kg}^{-1}\right)$ & $0.555^{\mathrm{a}}$ & $0.085^{\mathrm{a}}$ & $1.988^{\mathrm{a}}$ & 5.06 & 0.400 & 0.057 & $2.112^{\mathrm{ab}}$ & $4.85^{\mathrm{ab}}$ \\
\hline Atorvastatin $\left(20 \mathrm{mg} \mathrm{kg}^{-1}\right)$ & $0.400^{\mathrm{b}}$ & $0.085^{\mathrm{a}}$ & $1.833^{\mathrm{ab}}$ & 4.61 & 0.333 & 0.054 & $2.088^{\mathrm{ab}}$ & $4.35^{\mathrm{b}}$ \\
\hline SEM & 0.034 & 0.007 & 0.093 & 0.221 & 0.045 & 0.003 & 0.068 & 0.390 \\
\hline $\mathrm{p}$-value & 0.0391 & 0.6719 & 0.0253 & 0.3944 & 0.0835 & 0.923 & 0.0224 & 0.0001 \\
\hline
\end{tabular}

Table 6: Wilcoxon score for variable of liver scores classified by variable feed in Broilers chickens

\begin{tabular}{|c|c|c|c|c|c|c|c|c|}
\hline \multirow[b]{2}{*}{ Treatments } & \multicolumn{4}{|c|}{ Liver score, $35 \mathrm{~d}$} & \multicolumn{4}{|c|}{ Liver score, $42 \mathrm{~d}$} \\
\hline & Score 0 & Score 1 & Score 2 & Score 3 & Score 0 & Score 1 & Score 2 & Score 3 \\
\hline Control & 20.00 & 17.86. & 22.69 & 34.33 & 00.00 & 10.4 & 77.78 & 100.00 \\
\hline Silymarin (250 mg kg-1) & 00.00 & 21.42 & 18.69 & 00.00 & 23.08 & 20.69 & 00.00 & 0.00 \\
\hline Artichoke (200 mg kg-1) & 20.00 & 25.00 & 10.34 & 16.67 & 19.23 & 20.69 & 11.11 & 0.00 \\
\hline Olive (150 $\left.\mathrm{mg} \mathrm{kg}^{-1}\right)$ & 60.00 & 14.29 & 10.34 & 32.33 & 15.38 & 24.14 & 11.11 & 0.00 \\
\hline Gemfibrozil (1800 mg kg${ }^{-1}$ ) & 00.00 & 10.71 & 17.24 & 16.67 & 19.23 & 13.79 & 00.00 & 0.00 \\
\hline Atorvastatin $\left(20 \mathrm{mg} \mathrm{kg}^{-1}\right)$ & 00.00 & 10.71 & 20.69 & 00.00 & 23.08 & 10.34 & 00.00 & 0.00 \\
\hline $\mathrm{p}$-value & 0.0404 & $<0.0001$ & $<0.0001$ & 0.0352 & $<0.0001$ & $<0.0001$ & $<0.0012$ & 0.0833 \\
\hline Chai-square & 10.00 & 140.00 & 145.00 & 18.00 & 104.00 & 145.00 & 18.00 & 2 \\
\hline
\end{tabular}

in the birds grown on the control diet compared with those fed with the plant extracts and atorvastatin supplemented diets at day 42 of age (Table 5).

Apparent liver health was appraisedbased on liver color and scored from 0-3 ( $<<0.05$; Table 6$)$. At day 35 of age, the relative frequency of scores 2 and 3 were greater for control birds and significantly reduced in those receiving diets supplemented with all feed additives. Birds receiving silymarin- and Atorvastatin-added diets, in particular showed improved liver health at the same age indicating by no liver with score 3 for the same birds. At the advanced age (42 d), a prominent hepatoprotective effect was realized for all additives where greater frequency for scores 2 and 3 in control birds significantly minimized in all birds receivingthe supplemented diets (Table 6).

\section{DISCUSSION}

Normal fat percentage in broiler chicken liver tissue has been reported in a range of $2-5 \%{ }^{[14]}$ and liver fat percentage beyond $5 \%$ has been described as $\mathrm{FLS}^{[15]}$. In the current study, the formulation usedfor the basal grower diet commendably induced FLS, evidenced by increased liver fat, serum activity of liver enzymes (ALT and AST) and serum concentration of TP, ALB, TBIL, TG and $\mathrm{CHO}$ at days 35 and/or 42 of age. All these indications were anticipated in the birds fed with our lipogenic pelleted diet. In other words, we succeed to induce FLS in the experimental flockby feeding the lipogenic grower diet. Therefore, we hypothesized that administration of the selected herbal remedies and two commonly used chemical medications (gemfibrozil and atorvastatin) may modulate the adverse effects of the highly digestible pelleted diet on liver function in broiler chicken. Our expectation realized, however, neither consistent alteration in all parameters evaluated were observed in favor of a single medication nor changes revealed for a selected medication could be manifested in the two recording ages and in an obvious pattern.

Supplementation of milk thistle in the basal diet increased LDH, TC and TG while significantly decreased liver fat, abdominal fat and simultaneously reduced serum concentrations of ALB, TP and activityof the enzymes concerned. These out comes in part, agrees Gawel et al. ${ }^{[16]}$, findings who observed increased slaughter weight in chicken and turkeys maintained on diets containing silymarin. Metwally et al. ${ }^{[17]}$ also observed reduced serum total lipids, TC and triglycerides in rats fed on a high cholesterol diet following treatment with silymarin (25, 50 and $100 \mathrm{mg} \mathrm{kg}^{-1}$ ). Previous scientific evidences demonstrated that cholesterol and triglyceride lowering effects of silymarin may result from its active compounds which act as inhibitors to hepatic 3-hydroxyl, 3-methyglutaryl coenzyme-A reductase (HMG-CoA reductase) enzyme in mevalonate pathway where it operates as the rate limiting step in the biosynthesis of cholesterol and isopernoides ${ }^{[18]}$. It has been demonstrated that elevated liver enzymes activity has directly associated with higher concentrations of inflammatory markers such as C-reactive protein ${ }^{[19]}$ and therefore, it seems that the impact of silymarin on decreasing liver enzymes can be 
mediated by its suppressing effects on inflammatory biomarkers. In addition, silymarin promote hepatic glutathione generation by increased cysteine availability and inducing cysteine synthesis while preventing its catabolic conversion to taurine, the regulation of cysteine generation may then subsidize to the antioxidant defense ${ }^{[20]}$.

In the current study, inclusion of olive extract in the basal diet decreased liver fat by $1.60 \%$ compared with those fed with the basal diet. Moreover, serum concentration of TP, TG, abdominal fat and liver enzymes lowered in the same birds, the evidences which encouraged us to declare the possible hepatoprotective effects for olive extract. Tufarelli et al. ${ }^{[21]}$, revealed that dietary supplementation of $2.5 \%$ olive oil increased antioxidant activity evidenced by reduced lipid peroxidation in chicken liver. Our results are in the line with finding of Wani et al. ${ }^{[22]}$ who reported that rats maintained on a lipogenic diet possess greater number of lipid droplets in the liver sections than the olive oil- treated animals. In their study, inclusion of olive oil lessened serum triglycerides, normalized the liver enzymes and significantly decreased fat droplet deposits in liver through overwhelming inflammation and renovating the abnormal lipid metabolism in the experimental animals. Results of the current study propose olive oil may influence energy homeostasis mechanisms particularly in liver and moderatehepatic lipid build up. The hepatoprotective and lipid/cholesterol lowering effects of olive extract is thought to come from oleuropein, a predominant antioxidant substance in olive leaves ${ }^{[23]}$. Moreover, olive oil can reduce the intestinal absorption of cholesterol, or decrease its synthesis by liver $^{[24]}$.

Inclusion of artichoke extract into the basal diet decreased liver fat by about $1.21 \%$ and exerted positive effects on certain serum indicators as specified by decreased serum concentrations of TG, TC and TP compared with those fed with the non-supplemented control diet. Moreover, artichoke extract had a nonsignificant positive effect on decreasing liver score and abdominal fat compared with the basal diet. Azcona etc., reported a higher metabolizable energy froma diet when it was supplemented with artichoke extract during the first 21 days of broiler's life. These researchers explained such beneficial effects by a higher lipid digestibility in the same birds due to an increased bile secretion due to the metabolic effects of cynarin (a hydroxycinnamic acid) as the major biologically active chemical constituent in artichoke. Xuchong et al. ${ }^{[25]}$, observed that serum concentration of AST and TG decreased by inclusion of $1.6 \mathrm{~g} \mathrm{~kg}^{-1}$ BW artichoke into a broiler diet. The anticipated mechanism of hepatoprotective and lipid lowering effects for artichoke extracts may arise form interactions of luteolin with hydroxyl methyl glutaryl
coenzyme-A reductase, liver sterol regulatory element binding proteins and acetyl CoA C-acetyl transferase ${ }^{[26]}$. Moreover, it was also shown that certain constituents in artichoke extract exert potential lowering cholesterol effect by increase flow of bile salts in excreta ${ }^{[27]}$.

An attractive part of our study was the comparisons between medical remedies with the commonly used synthetic medications in human treatment for their possible hepatoprotective properties. In the present study, administration of atorvastatin through the basal diet reduced abdominal and liver fat percentage in broiler chicken in day 42 of age. Studies with statins and their effects in poultry species are scanty. In the study of Jose et al. ${ }^{[28]}$ no significant effect of atorvastatin on bilirubin, albumin and total protein were observed in patients of hyperlipidemia. However, it has been shown that statins upregulate LDL-receptors in cells therefore lipids movement into the cell may arise which led to increased lipid flow into mitochondria ${ }^{[29]}$. Golrokh et al. ${ }^{[30]}$ reported a decrease in serum triglyceride and cholesterol concentrations in response to dietary supplementation with atorvastatin $\left(2 \mathrm{~g} \mathrm{~kg}^{-1}\right)$ in broiler chickens.

Inclusion of gemfibrozil into the diet significantly deceased liver and abdominal fat percentage in broiler chicken at days 35 and 45 of age. Gemfibrozil impede fatty acid metabolism to influence lipid redistribution in favor of increased overall intramuscular fat, a phenomenon which improve carcass quality and nutritive value in broilers ${ }^{[31]}$. Additionally, the same research team demonstrated that gemfibrozil acts as an activator of Peroxisome Proliferator-Activated Receptor- $\alpha$ (PPAR $\alpha$ ), a nuclear receptor involving differentiation of adipose tissue and metabolisem of carbohydrates and lipids. Gemfibrozil is used therapeutically to decline blood triglyceride and cholesterol concentrations in humans. There are evidences displaying gemfibrozil administration can raise serum AST activity in human and rat ${ }^{[32]}$. We do not confirm the same effects in broiler chicken, as no increase in serum ALT and AST activity observed in the birds grown on the gemfibrozil-added diet.

Considering the whole results, milk thistle, olive and artichoke extracts as well as gemfibrozil and atorvastatin demonstrated hepatoprotective, lipid and cholesterol lowering effects in broiler chickens fed with a lipogenic diet in a high digestible (pelleted) physical form. However, among plant remedies examined, milk thistle showed greater promising effects evidenced by $2.13,0.52$ and 31.65 reduction in fat liver, abdominal fat and serum concentrations of TC compared with the birds receiving the basal diet, respectively. Similarly, gemfibrozil exhibited a greater hepatoprotective and blood lipid lowering effect than atorvastatin and all three herbal extracts used, except for milk thistle which their effects were obviously comparable. Statins are effective lipid-lowering agents, associated with a depressing the 
risk of cardiovascular events in several interventional randomized clinical trials with human cases ${ }^{[33]}$. However, our results showed no priority for atorvastatin over gemfibrozil for their hepatoprotective effects in broiler chickens grown on a lipogenic diet.

In the face of the current therapeutic achievements, more concern has presently been devoted to plant derivedproducts as the conceivable means to alleviate FLS and its associated symptomsin birds ${ }^{[34]}$. We agree such ascended concerns, since, phytogenic products are locally available, cost effective, and physiologically safe. Moreover, theyexert minimal side effects compared to the synthetic therapeutics. Our results suggested all three remedies used as potential candidates for the same purpose. However, the outcome acts in favor of milk thistle, commented by many beneficial effects on reduced fat liver, serum activity of liver enzymes and certain serum biochemical markers in the birds maintained on a lipogenic pelleted diet.

\section{CONCLUSION}

Based on the results achieved all herbal remedies used viz. milk thistle, olive, artichoke extracts as well as the two commonly prescribed synthetic medications (gemfibrozil and atorvastatin) demonstrated considerable hepatoprotective, lipid and cholesterol lowering effects in broiler chickens maintained on a pelleted lipogenic diet. However, milk thistle showed greater promising effects compared with other remedies. Gemfibrozil exhibited a greater hepatoprotective and blood lipid lowering effect than atorvastatin and all three herbal remedies.

\section{ACKNOWLEDGEMENTS}

The researchers wish to thank R. Karimirad, S. Azadbakht, O, Hasanvand, T. Pakzad, F. Delfan and S.A. Nouraldinei, Dept. of Animal Sciences, Agriculture Faculty, Lorestan University, Khoramabad, Iran, University, Lorestan, Iran, for their thechnical helps during the experimentation period.

\section{REFERENCES}

01. Ayala, I., A.M. Castillo, G. Adanez, A. Fernandez-Rufette, B.G. Perez and M.T. Castells, 2009. Hyperlipidemic chicken as a model of non-alcoholic steatohepatitis. Exp. Biol. Med., 234: 10-16.

02. Cherian, G., T. Holsonbake, M. Goeger and R. Bildfell, 2006. Dietary CLA alters yolk and tissue FA composition and hepatic histopathology of laying hens. Lipids, 37: 751-757.
03. Makovick, P., M. Dudova, E. Tumova, R. Rajmon and Z. Vodkova, 2011. Experimental study of Non-Alcoholic Fatty Liver Disease (NAFLD) on a model of starving chickens: Is generalization of steatosis accompanied by fibrosis of the liver tissue?. Pathol. Res. Pract., 207: 151-155.

04. Xiao, J., R. Guo, M.L. Fung, E.C. Liong and G.L. Tipoe, 2013. Therapeutic approaches to non-alcoholic fatty liver disease: Past achievements and future challenges. Hepatobiliary Pancreatic Dis. Int., 12: 125-135.

05. Onel, S.E., S. Sungur and M. Baylan, 2017. Effects of supplementary choline on quail meat and fatty liver. Braz. J. Anim. Sci., 46: 645-651.

06. Hillgartner, F.B., L.M. Salati and A.G. Goodridge, 1995. Physiological and molecular mechanisms involved in nutritional regulation of fatty acid synthesis. Physiol. Rev., 75: 47-76.

07. Khosravinia, H., P.S. Chethen, B. Ukmakantha and R. Nourmohamadi, 2015. Effects of lipotropic products on productive performance, liver lipid and enzymes activity in broiler chickens. Poult. Sci., 3: $113-120$.

08. Ferramosca, A., M. Di Giacomo and V. Zara, 2017. Antioxidant dietary approach in treatment of fatty liver: New insights and updates. Worlds J. Gastroenterol., 23: 4146-4157.

09. Elliott, R.J., 1984. Physicians and computers: Ektachem DT-60 analyzer. Phys. Lead, 2: 6-13.

10. Trott, K.A., F. Giannitti, G. Rimoldi, A. Hill, L. Woods and B. Barr, 2013. Fatty liver hemorrhagic syndrome in the backyard chicken: A retrospective histopathologic case series. Vet. Pathol., 51: 787-795.

11. Folch, J., M. Lees and G.H.S. Stanley, 1957. A simple method for the isolation and purification of total lipides from animal tissues. J. Biol. Chem., 226: 497-509.

12. Kramer, C.Y., 1956. Extension of multiple range tests to group means with unequal numbers of replications. Biometrics, 12: 307-310.

13. SAS., 2003. SAS users guide: Statistics. Ver. 6. Cary, NC, Statistical Analysis System, USA.

14. Hoyumpa, A.M., H.L. Greene, G.D. Dunn and S. Schenker, 2005. Fatty liver: Biochemical and clinical considerations. Dig. Dis. Sci., 20: 1142-1170.

15. Corey, K.E. and N. Chalasani, 2013. Management of dyslipidemia as a cardiovascular risk factor in individuals with nonalcoholic fatty liver disease. Clin. Gastroenterol. Hepatol., 12: 1077-1084.

16. Gawel, A., B. Kotonski, J.A. Madej and M. Mazurkiewicz, 2003. Effect of silymarin on chicken and turkey broilers' rearing and the production indices of reproduction hen flocks. Med. Weter., 59: 517-520. 
17. Metwally, M.A.A., A.M. El-Gellal and S.M. El-Sawaisi, 2009. Effects of silymarin on lipid metabolism in rats. World Applied Sci. J., 6: 1634-1637.

18. Nagashima, S., H. Yagyu, K. Ohashi, F. Tazoe, M. Takahashi and T. Ohshiro, 2012. Liver-specific deletion of 3-hydroxy-3-methylglutaryl coenzyme A reductase causes hepatic steatosis and death. Arterioscler. Thromb. Vasc. Biol., 32: 1824-1831.

19. Kulkarni, Y.A., V.U. Yele, V. Addepalli and K.S. Kulkarni, 2012. Non-alcoholic fatty liver disease: Introspection. Pharmocology OnLine, 3: 104-112.

20. Kwon, D.Y., Y.S. Jung, S.J. Kim, Y.S. Kim, D.W. Choi and Y.C. Kim, 2013. Alterations in sulfur amino acid metabolism in mice treated with silymarin: A novel mechanism of its action involved in enhancement of the antioxidant defense in liver. Planta. Med., 79: 997-1002.

21. Tufarelli, V., V. Laudadio and E. Casalino, 2016. An extra-virgin olive oil rich in polyphenolic compounds has antioxidant effects in meat-type broiler chickens. Environ. Sci. Pollut. Res., 23: 6197-6204.

22. Wani, F.A., Z.A. Albahrawy and S. Rahiman, 2015. Hypolipidemic activity of olive oil (Olea europaea) against high fat diet-induced Nonalcoholic Fatty Liver Disease (NAFLD) in mice. Open J. Pathol., 05: 73-83.

23. Andrikopoulos, N.K., S. Antonopoulou and A.C. Kaliora, 2002. Oleuropein inhibits LDL oxidation induced by cooking oil frying by-products and platelet aggregation induced by platelet-activating factor. LWT-Food Sci. Technol., 35: 479-484.

24. Krzeminski, R., S. Gorinstein, H. Leontowicz, M. Leontowicz, M. Gralak and J. Czerwinski, 2003. Effect of different olive oils on bile excretion in rats fed cholesterol-containing and cholesterol-free diets. J. Agric. Food Chem., 51: 5774-5779.

25. Xuchong, T., W. Ruofan, D. Aihua and L. Tingping, 2017. Protective effects of ethanolic extracts from artichoke, an edible herbal medicine, against acute alcohol-induced liver injury in mice. Nutrients, Vol. 9, No. 9. 10.3390/nu9091000
26. Gebhardt, R., 2002. Inhibition of cholesterol biosynthesis in HepG2 cells by artichoke extracts is reinforced by glucosidase pretreatment. Phytother. Res., 16: 368-372.

27. Qiang, Z., S.O. Lee, Z. Ye, X. Wu and S. Hendrich, 2012. Artichoke extract lowered plasma cholesterol and increased fecal bile acids in golden Syrian hamsters. Phytother. Res., 26: 1048-1052.

28. Jose, M.A., S. Anandkumar, M.P. Narmadha and M. Sandeep, 2012. A comparative effect of atorvastatin with other statins in patients of hyperlipidemia. Indian J. Pharmacol., 44: 261-263.

29. Arslan, C., M. Citil and M. Saatci, 2003. Effects of L-carnitine administration on growth performance, carcass traits, blood serum parameters and abdominal fatty acid composition of ducks. Arch. Anim. Nutr., 57: 381-388.

30. Golrokh, A.J., M. Bouyeh, A. Seidavi, R.V.D. Hoven, V. Laudadio and V. Tufarelli, 2016. Effect of different dietary levels of atorvastatin and l-carnitine on performance, carcass characteristics and plasma constitutes of broiler chickens. J. Poultr. Sci., 53: 201-207.

31. Farrokhyan, P., M. Bouyeh, F.M. Lartey and A. Seidavi, 2014. The effects of dietary L-carnitine and gemfibrozil on performance, carcass characteristics, cholesterol and triglycerides in broiler chicks. Avian. Biol. Res., 7: 160-166.

32. Kolovou, G.D., D.P. Mikhailidis, N. Kafaltis, E.N. Adamopoulou and E. Yazitsoglou et al., 2004. The effect of alcohol and gemfibrozil co-administration in Wistar rats. In Vivo, 18: 49-54.

33. Pastori, D., L. Polimeni, F. Baratta, A. Pani, M. Del Ben and F. Angelico, 2014. The efficacy and safety of statins for the treatment of non-alcoholic fatty liver disease. Dig. Liver Dis., 47: 4-11.

34. Guo, X., H. Cao, G. Hu, C. Zhang and H. Li et al., 2012. Effect of high-energy low-protein diet supplemented with biotin on fat metabolism of laying hens. Chin. J. Vet. Sci., 32: 754-758. 